\title{
OPTIMIZATION OF BIODIESEL PRODUCTION USING A STIRRED PACKED-BED REACTOR
}

\author{
Farid Nasir Ani ${ }^{*}$, Nur Hamzah Said ${ }^{1,3}$, Mohd. Farid Muhamad Said ${ }^{2}$ \\ ${ }^{1}$ Department of Thermofluid, Faculty of Mechanical Engineering, Universiti Teknologi Malaysia, Johor \\ Bahru 81310 Johor, Malaysia \\ ${ }^{2}$ Automotive Development Centre, Faculty of Mechanical Engineering, Universiti Teknologi Malaysia, \\ Johor Bahru 81310 Johor, Malaysia \\ ${ }^{3}$ Department of Mechanical Engineering, State Polytechnic of Ujung Pandang, Makassar 90245, \\ Indonesia
}

(Received: January 2017 / Revised: January 2017 / Accepted: February 2018)

\begin{abstract}
The use of waste cooking oil (WCO) as feedstock and in microwave heating technology helps to reduce the cost of biodiesel. In this study, a continuous flow transesterification of waste cooking oil (WCO) by microwave irradiation for biodiesel production using calcium oxide $(\mathrm{CaO})$ as aheterogeneous catalyst, calcined from cockle shells, is used. The catalyst was packed inside a plastic perforated container mounted on a stirrer shaft and inserted inside the reactor. The thermocouple inside the reactor was connected to a temperature controller and microwave power input to maintain the temperature. Response surface methodology (RSM) was employed to study the relationships between power input, stirrer speed and liquid hourly space velocity (LHSV) on the WCO methyl ester (WCOME) conversion at a fixed molar ratio of methanol to oil of 9 and a reaction temperature set at $65^{\circ} \mathrm{C}$. The experiments were developed using the Box-Behnken design (BBD) for optimum conditions. The transesterification of the WCO was produced at $72.5 \%$ maximum WCOME conversion at an optimum power input of $445 \mathrm{~W}$, stirrer speed of 380 $\mathrm{rpm}$ and LHSV of $71.5 \mathrm{~h}^{-1}$. The energy consumption in a steady state condition was $0.594 \mathrm{kWh}$ for the production of 1 litre WCOME, for this heterogeneous catalyst is much faster than conventional heating.
\end{abstract}

Keywords: $\quad$ Box-Behnken design; Calcium oxide; Microwave; Optimization; Waste cooking oil

\section{INTRODUCTION}

Biodiesel belongs to the category of alternative diesel fuels and can be produced from animal fats and vegetable oils, which are generally referred to as renewable biological sources. Research activities on the production of biodiesel have been on the increase in recent times due largely to the surge in the price of petroleum products and the environmental friendliness of biodiesel. The use of biodiesel blends has led to a reduction in the levels of greenhouse gases, such as $\mathrm{CO}_{2}(\mathrm{Balat}$ \& Balat, 2010). A major impediment to the full commercialization of biodiesel is the high cost of production. Thus, one way of reducing this cost is through the use of inexpensive raw materials such as WCO (Hamze et al., 2015). From the environmental point of view, the use of WCO reduces the disposal problem.

The environmental problem caused by the disposal of WCO through direct discharge into water drainage systems has led policymakers in many developed countries to develop policies that

*Corresponding author's email: farid@mail.fkm.utm.my, Tel. +61-07-5534715, Fax.+61-07-5566159

Permalink/DOI: https://dx.doi.org/10.14716/ijtech.v9i2.1386 
stipulate stiffer penalties for violators (Kathirvel et al., 2016). With this in mind, the use of WCO as feedstock can create a safe and clean environment (Kusrini et al., 2015).

Hence, researchers have been focusing on using WCO as a feedstock for diesel fuel (Muralidharan \& Vasudevan, 2011; Chen et al., 2012). The conversion of fats and oils into biodiesel has been carried out by researchers employing various methods, such as pyrolysis, catalytic cracking and transesterification (Rathore et al., 2016). Among these methods, transesterification is noted for the production of high quality biodiesel (Talebian-Kiakalaieh et al., 2013). Transesterification, also known as alcoholysis, involves the formation of glycerol and esters through the reaction of alcohol with either oil or fat. The reaction type and temperature, type of alcohol, agitation speed, concentration of catalyst, water content, alcohol to oil molar ratio, and FFA of the feedstock are the core process factors that usually influence the transesterification process (Hamze et al., 2015). Compared with conventional heating, the applications of microwave irradiation in biodiesel production have led to a considerable reduction in the reaction time and an increase in the biodiesel yield (Motasemi \& Ani, 2012). Besides that, enhancement in the rate of reaction and the yield can also be facilitated through the use of a catalyst. Unlike conventional heating, this method can operate at over $90 \%$ efficiency and is ecofriendly in a variety of chemical reactions (Lam et al., 2016).

In addition, the catalyst plays a decisive role in the process of transesterification. Catalysts are classified as either homogeneous or heterogeneous, based on the type of chemicals that are present in the transesterification reaction. Catalysts are said to be homogeneous when they act in a liquid phase which is the same as the reaction mixture. On the other hand, heterogeneous catalysts are those that act in a phase that is different from the reaction mixture, commonly as a solid (Borges \& Díaz, 2012). Heterogeneous catalysts are a green process, are eco-friendly and non-corrosive. They have good recyclability, and as such can be used many times possible, thus offering a cost-effective way for the production of biodiesel (Said et al., 2015). The application of calcium oxide $(\mathrm{CaO})$ derived from waste carbonaceous materials is a potential solid catalyst in the biodiesel production process (Yusuff et al., 2018).

The use of conventional transesterification in batch operations has been considered rigorous, tedious, slow and unsuitable for automation adaptation. Besides that, it has a low cost of production, the ability to only produce very small quantities of biodiesel, the capacity to make improvements to the design of equipment for the optimization of the quality of biodiesel, and the ability to produce greater quantities of biodiesel per unit of labour are some of the advantages of the continuous flow transesterification (Chen et al., 2010).

During the transesterification process, the reactants, triglycerides such as WCO and methanol, are considered immiscible due to their inability to properly mix together and form a mixture with a single layer. The liquid-solid mass transfer resistance between the solid catalyst and reactants can be reduced by increasing the mass transfer and micromixing efficiencies using a stirring packed-bed reactor (Chen et al., 2010; Li et al., 2013).

Several continuous flow reactors using heterogeneous catalysts to produce biodiesel from WCO (Borges \& Díaz, 2013; Buasri et al., 2012). Application of RPB in conventional heating has been widely used, particularly the use of the WCO as a raw material. It is clear that residence time is relatively long compared to microwave heating. Although using microwave irradiation can produce biodiesel with a low residence time, conversion obtained from this system is still low.

Response surface modelling (RSM) has been applied widely in the development and optimization of various synthesis processes and for the optimization of analytical chemistry processes. It is a powerful statistical and mathematical tool with several advantages (Pinzi et al., 2010). Dwivedi and Sharma (2015) carried out optimization of the four process factors namely methanol/oil molar ratio, catalyst amount, reaction time and temperature reaction through the implementation of Box- 
Behnken RSM in order to obtain maximum biodiesel yield from Pongamia oil.

The objective of this paper is to report on continuous flow transesterification of WCO using microwave irradiation for biodiesel production, in which the solid catalyst was placed in a catalyst container stirrer. It is interesting to optimize conversion of three process variables, namely power input, stirrer speed and LHSV, for the transesterification process of WCO using RSM-based BBD in 15 experimental runs, with the help of Design Expert version 7.0 software.

\section{MATERIALS AND METHODS}

\subsection{Material}

Methanol analytical reagent (AR) grade was purchased from QRëC, New Zealand. The WCO obtained from restaurants containing FFA $(0.41-0.48 \%)$ usually contains food waste in the form of solids. Therefore, filtering is necessary. Besides, water content in the WCO needs to be removed by evaporation. Evaporation of any water can be done by heating the oil in an electric oven at $110^{\circ} \mathrm{C}$ for $4 \mathrm{~h}$. After that, the $\mathrm{WCO}$ is ready for the transesterification process.

The catalyst was $\mathrm{CaO}$, made from cockle shells. They were crushed using a hammer and sieved to a size of $2 \mathrm{~mm}$ to $4 \mathrm{~mm}$. Subsequently, the shells were decomposed in a furnace at a temperature of $900^{\circ} \mathrm{C}$ for $3.5 \mathrm{~h}$ by the method performed by Nair et al. (2012). After the cold solids were obtained, they were stored in a desiccator before use in the transesterification process. Characterization was performed using X-ray diffraction (XRD) to observe the structure of the metal oxide formed. The characterization results obtained were compared with JCPDS data, which are the standards for XRD diffraction pattern data and decomposition of cockle shells.

\subsection{Transesterification Process of Waste Cooking Oil}

\subsubsection{Experimental set-up}

The experiment was carried out using a $1 \mathrm{~kW}$ domestic modified microwave system with a frequency of $2450 \mathrm{MHz}$. The microwave power can be selected at different levels from 100 to $1000 \mathrm{~W}$ and for various exposure times $(1-90 \mathrm{~min})$. A reactor made of borosilicate with a diameter of $50 \mathrm{~mm}$ and a length of $210 \mathrm{~mm}$ was placed in the microwave.

The catalyst was packed inside a perforated plastic container mounted on a stirrer shaft and inserted inside the reactor. Three holes were drilled in the top reactor cover of the domestic microwave oven in order to place the reactor inside it. Two K-type metallic thermocouples were used to measure the temperature of the methanol mixture and the $\mathrm{WCO}$; one was inserted from the bottom of the reactor (T1) and one at the top of the reactor (T2). The thermocouples were connected to a Pico data acquisition system, which in turn was connected to a personal computer for continuous recording of the data using Picolog software. The thermocouple (T1) was also connected to a temperature controller and microwave power input to maintain the temperature. The microwave and thermocouple were grounded to avoid any discrepancy in temperature readings or sparks.

The rotation of the packed bed was made using an overhead high-speed stirrer (WiseStir model HS-30D) equipped with a digital speed regulator. Stirrer speeds of 200, 300 and $400 \mathrm{rpm}$ were used in this research. The rotation of the packed bed helped to increase the contact between the catalyst and the reactants. The experimental set-up for single step transesterification continued the process with the catalyst container stirrer, as shown in Figure 1.

The flowrate of WCO was regulated using a peristaltic pump, whose speed can be varied in direct proportion to the flow rate. The molar ratio of alcohol to oil and reaction temperature were fixed at 9:1 (Aworanti et al., 2013; Buasri et al., 2013) and $65^{\circ} \mathrm{C}$ (Buasri et al., 2013), respectively. The weight of the catalyst varied between $10.00,12.73$ and $20.00 \mathrm{~g}$. The flow rate of WCO was 
regulated by setting the speed of the peristaltic pump at 24, 28 and $32 \mathrm{rpm}$, while the alcohol was put into the reactor using a syringe.

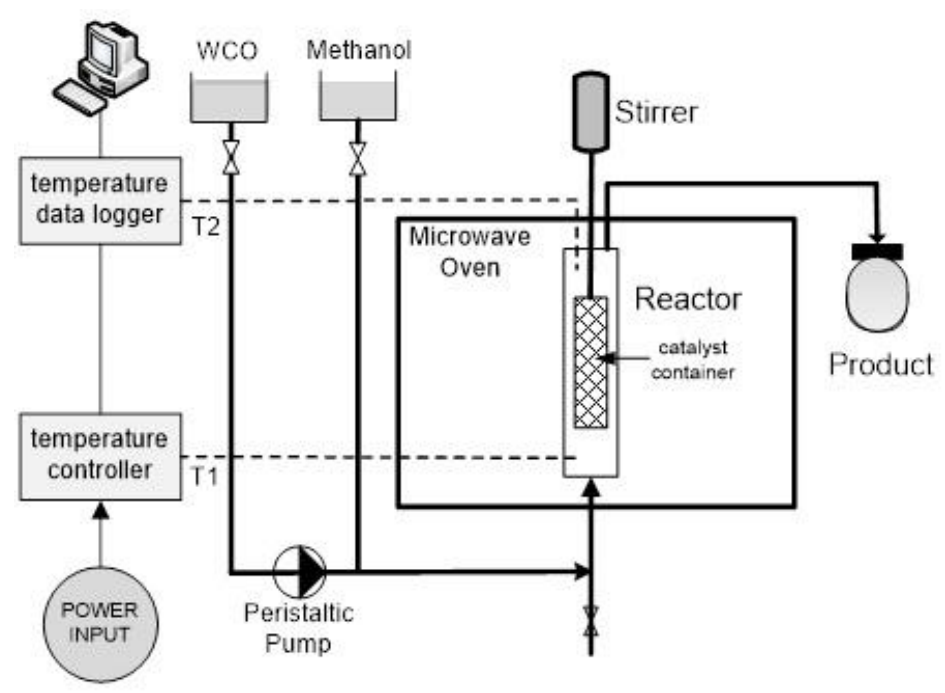

Figure 1 Experimental set-up for continuous transesterification process with a stirred packed-bed

\subsubsection{Experimental set-up}

The catalyst was weighed and inserted into the container. A container was fixed onto the stirrer shaft and inserted into the glass reactor. Methanol was then poured into the glass reactor and a moveable cover attached to the top of a reactor. The stirrer speed was set and the temperature controlled. The process of dispersing the methanol and catalyst was made at $65^{\circ} \mathrm{C}$ for 20 min. The WCO was then streamed through the bypass valve until the reactor was full. The bypass valve was closed and the peristaltic pump turned on. Sampling was made after the process time reached the space-time. The sample was collected in $10 \mathrm{~mL}$ glass vials and centrifuged at 4000 $\mathrm{rpm}$ for $10 \mathrm{~min}$. The product mixture was then exposed to open air for $30 \mathrm{~min}$. to evaporate the excess methanol (Aworanti et al., 2013). Subsequently, the chemical and physical properties were analyzed.

\subsection{Conversion of FFA}

The effect of different parameters on the FFA conversion of WCO methyl ester (WCOME) that are investigated are catalyst weight, flowrate, stirrer speed and power input, with the molar ratio and reaction temperature kept constant. The reaction products were analyzed by gas chromatography (GC) using the Perkin Elmer Auto system GS FID equipped with a flameionization detector (FID) through the capillary GC column BP5, $30 \mathrm{~m}$ in length, $0.25 \mathrm{~mm}$ ID and 0.25 micrometers. Comparison with authentic samples was carried out in order to identify the reactants and products. The palmitic acid (hexadecanoic acid methyl ester) conversion is given by the following equation (Han et al., 2016):

$$
\text { Conversion }(\%)=100 \% \times\left(1-\left(\mathrm{a}_{1} / \mathrm{a}_{2}\right)\right)
$$

where $\mathrm{a}_{1}$ and $\mathrm{a}_{2}$ represent the initial and final stages of the reaction mixture, respectively. 


\subsection{Space-time and space-velocity}

According to Levenspiel (1999), for batch reactors the natural performance measure is the reaction time, while for flow reactors the proper performance measures are the space velocity and the space time. For a negligible change in volume, the residence time and the space-time $(\tau)$ in the batch reactor and ideal tubular reactor, respectively, are considered the same and are given by:

$$
\tau=\text { reactor volume/volumetric feedrate }
$$

The space velocity, which is the inverse of the space time, is given by:

$$
\text { Space velocity }=1 / \tau
$$

The liquid hourly space velocity (LHSV) in $\mathrm{h}^{-1}$ is a measure of the feed rate and is calculated using Equation 4 (Ancheyta, 2011).

$$
\text { LHSV }=\text { total volumetric flowrate/total catalyst volume }
$$

$$
\mathrm{LHSV}=60 \mathrm{~F} / \mathrm{V}_{\mathrm{c}}
$$

where $\mathrm{F}$ is flowrate in $\mathrm{ml} \mathrm{min}-1$ and $\mathrm{Vc}$ is the catalyst volume $(\mathrm{ml})$, so Equation 5 can be expressed in the following equation:

$$
\mathrm{LHSV}=60 \mathrm{~F} \times \rho_{\mathrm{c}} / \mathrm{W}_{\mathrm{c}}
$$

where $\mathrm{Wc}$ is the catalyst weight $(\mathrm{g})$ and $\rho_{\mathrm{c}}$ is the catalyst density $\left(\mathrm{g} \mathrm{ml}^{-1}\right)$.

\section{RESULTS AND DISCUSSION}

\subsection{Biodiesel Production}

The results of the biodiesel transesterification process of WCO using the packed bed stirrer are shown in Table 1. The kinematic viscosity of WCOME is lower than WCO. One major specification that a manufacturer of biodiesel needs to comply with is the kinematic viscosity. This indicates the amount of fatty acid methyl esters (FAME) contained in the biodiesel, thus signifying the degree of the reaction.

Table 1 Selected properties of WCO and WCOME

\begin{tabular}{lcrr}
\hline \multicolumn{1}{c}{ Properties } & Units & \multicolumn{1}{c}{ WCO } & \multicolumn{1}{c}{ WCOME } \\
\hline Calorific value & $\mathrm{kJ} \mathrm{kg}^{-1}$ & 43,522 & 38,049 \\
Density at $15^{\circ} \mathrm{C}$ & $\mathrm{kg} \mathrm{l}^{-1}$ & 0.917 & 0.870 \\
Flash Point & ${ }^{\circ} \mathrm{C}$ & 318.0 & 158.5 \\
Kinematic Viscosity at $40^{\circ} \mathrm{C}$ & $\mathrm{cSt}$ & 47.51 & 5.48 \\
\hline
\end{tabular}

The results of the test using GCMS show that one sample contains 97.91\% methyl ester,using a molar ratio of methanol to oil of 9:1, a temperature of $65^{\circ} \mathrm{C}$, power input of $450 \mathrm{~W}$, a stirrer speed of $400 \mathrm{rpm}$ and LHSV of $57.31 \mathrm{~h}^{-1}$. One of the biggest components is hexadecanoic acid methyl ester, which is then to be used in the calibration calculation.

\subsection{Experimental Design Results}

The experimental response and predicted response for the transesterification of WCOME at a time collected to space time ratio of $=1$ are shown in Table 2 . The predicted values of the output parameter are calculated using the following regression equation: 


$$
\begin{aligned}
C & =69.8236637+0.00341229 \mathrm{~A}+0.0155426 \mathrm{~B}-0.95253203 \mathrm{C} \\
& -1.644414 \times 10^{-5} A B+0.000126601 \times \mathrm{AC}+9.4621 \times 10^{-5} B C \\
& -9.4299 \times 10^{-7}\left(A^{2}\right)-2.08229 \times 10^{-5}\left(B^{2}\right)-0.000307651 \times(C)^{2}
\end{aligned}
$$

Table 2 Responses for transesterification of WCOME

\begin{tabular}{rccccc}
\hline \multirow{2}{*}{ Run } & $\begin{array}{c}\text { A:Power } \\
\text { input } \\
\text { (watts) }\end{array}$ & $\begin{array}{c}\text { B:Stirrer } \\
\text { speed } \\
\text { (rpm) }\end{array}$ & $\begin{array}{c}\text { C:LHSV } \\
(\mathrm{h}-1)\end{array}$ & $\begin{array}{c}\text { Conversion }(\%) \\
\text { Experimental } \\
\text { response }\end{array}$ & $\begin{array}{c}\text { Predicted } \\
\text { response }\end{array}$ \\
\hline 1 & 450 & 400 & 57.17 & 72.48 & 72.51 \\
2 & 315 & 300 & 57.17 & 72.09 & 71.93 \\
3 & 450 & 300 & 83.18 & 72.18 & 72.34 \\
4 & 315 & 400 & 31.19 & 72.11 & 72.11 \\
5 & 315 & 400 & 83.18 & 71.77 & 71.59 \\
6 & 315 & 200 & 31.19 & 71.75 & 71.94 \\
7 & 450 & 200 & 57.17 & 72.46 & 72.29 \\
8 & 180 & 300 & 83.18 & 70.05 & 70.07 \\
9 & 315 & 300 & 57.17 & 71.96 & 71.93 \\
10 & 180 & 200 & 57.17 & 70.49 & 70.47 \\
11 & 450 & 300 & 31.19 & 72.48 & 72.46 \\
12 & 315 & 300 & 57.17 & 71.75 & 71.93 \\
13 & 180 & 300 & 31.19 & 72.13 & 71.97 \\
14 & 315 & 200 & 83.18 & 70.43 & 70.44 \\
15 & 180 & 400 & 57.17 & 71.40 & 71.57 \\
\hline
\end{tabular}

The significance of each coefficient in Equation 7 was evaluated by the P-value, as shown in Table 3. The smaller the magnitude of this value, the more significant is the corresponding coefficient. Considering the linear effect, only two operating parameters were found to be significant terms in increasing the conversion in the final product. The power input term had the most significant linear effect, followed by LHSV and stirrer speed, respectively. In terms of the quadratic effect, no parameter was significant at the 5\% level. However, for the interaction effect, it was found that only power input-LHSV interaction was significant at this level. The other interaction terms had no significant effect on the WCOME conversion.

Table 2 shows that the value of the Model F-value of 19.23 means that the model is significant. Under this condition the "Prob> F" value of less than 0.0500 indicates a significant model term, three of which are the main parameters of power input, stirrer speed and LHSV. The interaction effect of power input-LHSV is also significant. If there are many insignificant model terms (not including those needed to support the hierarchy), model reductions can improve the model. The "lack-of-fit value" of 2.11 implies that lack of fit is insignificant compared to pure error. There is a possibility of $33.70 \%$ that this "lack-of-fit F-value" could be due to noise. The absence of an insignificant fit is good enough. The results in Table 3 also show that this model is acceptable, because it is significant and lack of fit is not significant. In addition, the power input parameters, stirrer speed, LHSV, and (power input $\times$ LHSV) are also significant.

The $\mathrm{R}^{2}$ value for WCOME conversion is 0.9719 . This means that $97.19 \%$ of the variability in the data are accounted for by the model, thereby validating the reliability of the model developed for establishing a correlation between the process variables and the WCOME conversion.

\subsubsection{Interactive effects of the variables on WCOME conversion}

The interaction of power input and stirrer speed at an LHSV of $71.5 \mathrm{~h}^{-1}$ on WCOME conversion is displayed in Figure 2. It is shown that for low power input, WCOME conversion increases with increasing stirrer speed. At high power input, WCOME conversion increases with stirrer speed until a certain point, and then decreases. Minimum WCOME occurs at minimum power input and 
minimum stirrer speed. This is due to the fact that both lower agitation and power transmission from microwave to mixture decrease the conversion. The yield value clearly increased when the speed was increased, because of the increase in the micro-mixing intensity between the oil and methanol phases (Chen et al., 2010).

Table 3 ANOVA for response surface quadratic model analysis of variance

\begin{tabular}{lcccccc}
\hline \multicolumn{1}{c}{ Source } & $\begin{array}{c}\text { Sum of } \\
\text { Squares }\end{array}$ & df & $\begin{array}{c}\text { Mean } \\
\text { Square }\end{array}$ & $\begin{array}{c}\text { F } \\
\text { Value }\end{array}$ & $\begin{array}{c}\text { p-value } \\
\text { Prob > F }\end{array}$ \\
\hline Model & 8.262845 & 9 & 0.918094 & 19.22902983 & 0.0023 & significant \\
A-Power Input & 3.830211 & 1 & 3.830211 & 80.22190583 & 0.0003 & \\
B-Stirrer Speed & 0.861057 & 1 & 0.861057 & 18.03442567 & 0.0081 & \\
C-LHSV & 2.045512 & 1 & 2.045512 & 42.84225667 & 0.0012 & \\
AB & 0.197064 & 1 & 0.197064 & 4.127410066 & 0.0979 & \\
AC & 0.789524 & 1 & 0.789524 & 16.53619519 & 0.0097 & \\
BC & 0.242002 & 1 & 0.242002 & 5.068608073 & 0.0742 & \\
A^2 & 0.001091 & 1 & 0.001091 & 0.022841231 & 0.8858 & \\
B^2 & 0.160096 & 1 & 0.160096 & 3.353141191 & 0.1266 & \\
C^2 & 0.159572 & 1 & 0.159572 & 3.342154705 & 0.1271 & \\
Residual & 0.238726 & 5 & 0.047745 & 2.114964134 & 0.3370 & \\
Lack of Fit & 0.181511 & 3 & 0.060504 & & & \\
Pure Error & 0.057215 & 2 & 0.028607 & & & \\
Cor Total & 8.501571 & 14 & & & & \\
\hline
\end{tabular}

\subsubsection{Optimization of response parameters}

The objective of optimization is to find the best setting value conditions based on the power input, stirrer speed and LHSV that produce the highest conversion value. Optimum conversion is obtained by setting the lower and upper limits of the variable process, namely power input, stirrer speed and LHSV. The percentage of conversion was set to maximum. It is implied that the model is significant and the lack-of-fit F-value insignificant, hence indicating that the model can be used to predict the conversion.
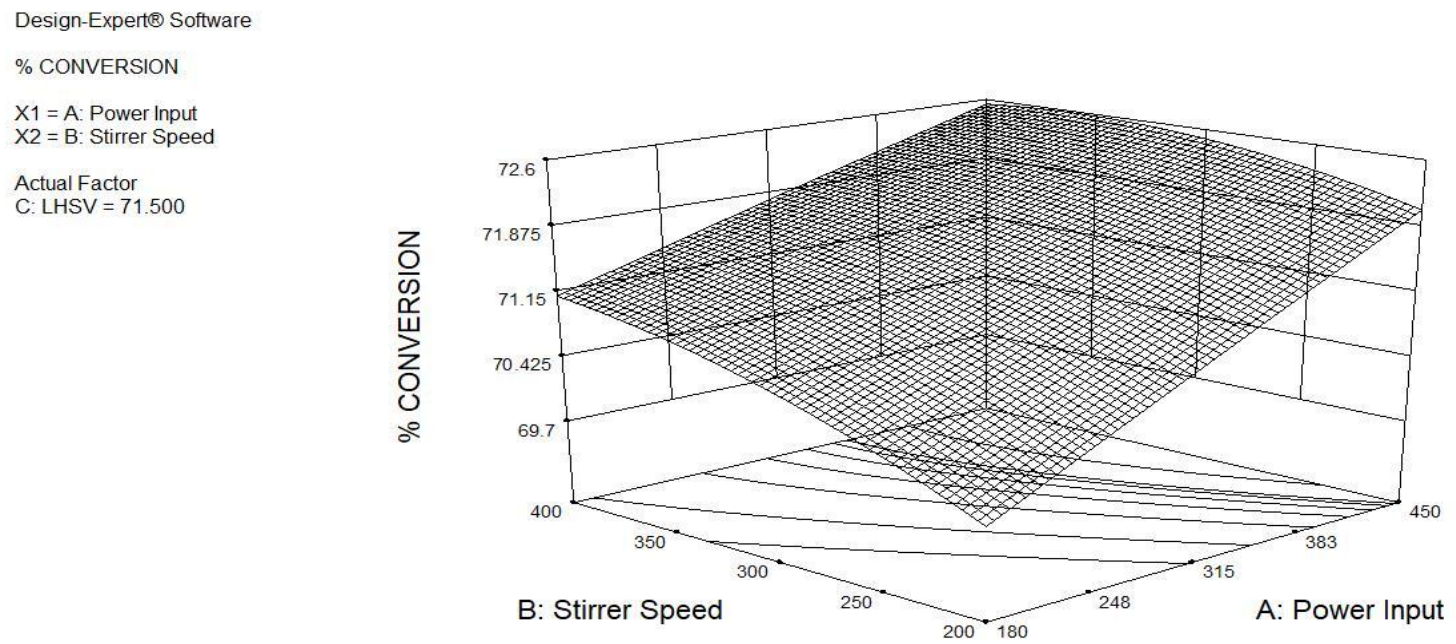

Figure 2 WCOME conversion versus power input and stirrer speed at LHSV=71.5 $\mathrm{h}^{-1}$

The response was optimized to maximize the WCOME conversion conditions for collected time same, as space time was based on the mathematical equation that was developed. The optimum value of the WCOME conversion of $72.52 \%$ was achieved with a power input of $445 \mathrm{~W}$, stirrer 
speed of $380 \mathrm{rpm}$ and LHSV of $71.5 \mathrm{~h}^{-1}$. The experiment was then validated in optimization conditions of power input of $450 \mathrm{~W}$, stirrer speed of $380 \mathrm{rpm}$ and LHSV of $71.5 \mathrm{~h}^{-1}$. The result of WCOME conversion at these levels was $72.5 \%$.

Some continuous flow biodiesel production research using heterogeneous catalysts is shown in Table 4, in which the residence time of MW heating is relatively shorter than when using conventional heating. Microwave irradiation can produce biodiesel with a shorter residence time, depending on the design requirements for fuel consumption in diesel engine power generation.

Table 4 Continuous flow biodiesel production of WCO using heterogeneous catalyst and its condition and performance

\begin{tabular}{|c|c|c|c|c|c|c|}
\hline \multirow[b]{2}{*}{ Catalyst used } & \multirow[b]{2}{*}{$\begin{array}{l}\text { Heating method } \\
\text { technology }\end{array}$} & \multicolumn{4}{|c|}{ Reaction conditions } & \multirow[b]{2}{*}{ Ref. } \\
\hline & & $\begin{array}{l}\text { Tempe- } \\
\text { rature } \\
\left({ }^{\circ} \mathrm{C}\right) \\
\end{array}$ & $\begin{array}{c}\text { Type of alcohol } \\
\text { (alcohol to oil } \\
\text { molar ratio) }\end{array}$ & $\begin{array}{c}\text { Residence } \\
\text { time- } \\
\text { (LHSV) }\end{array}$ & Performance & \\
\hline $\begin{array}{l}\text { Calcium oxide }(\mathrm{CaO}) \\
\text { from cockle shells } \\
\text { (lump size } 2-4 \mathrm{~mm}) \\
\end{array}$ & $\begin{array}{l}\text { Stirring packed-bed } \\
\text { reactor - microwave } \\
\text { heating }\end{array}$ & 65 & Methanol (9) & $\begin{array}{l}50.35 \mathrm{~min}^{-1} \\
\left(71.5 \mathrm{~h}^{-1}\right)\end{array}$ & $\begin{array}{l}\text { Conversion of } \\
\mathrm{FFA}=72.57 \% \\
(\max )\end{array}$ & $\begin{array}{l}\text { Present } \\
\text { work }\end{array}$ \\
\hline $\begin{array}{l}\text { Potassium-loaded } \\
\text { pumice material (K- } \\
\text { Pumice) }\end{array}$ & $\begin{array}{l}\text { Packed-bed } 8.2 \mathrm{~cm} \\
\text { in length - } \\
\text { conventional heating }\end{array}$ & 55 & Methanol (28) & $2 \mathrm{~h}$ & Yield $=95.9 \%$ & $\begin{array}{l}\text { Borges et } \\
\text { al } \\
(2013)\end{array}$ \\
\hline $\begin{array}{l}\text { Calcium oxide } \\
\text { supported on activated } \\
\text { carbon }(\mathrm{CaO} / \mathrm{AC})\end{array}$ & $\begin{array}{l}\text { Fixed bed reactor } \\
295 \mathrm{~mm} \text { packed bed } \\
\text { height - } \\
\text { conventional heating }\end{array}$ & 60 & Methanol (25) & $8 \mathrm{~h}$ & $\begin{array}{l}\text { Conversion } \\
=94 \%\end{array}$ & $\begin{array}{l}\text { Buari et } \\
\text { al (2012) }\end{array}$ \\
\hline
\end{tabular}

In an earlier study, for a microwave biodiesel production system using a homogeneous catalyst equipped with a mechanical stirrer, the energy for electrical consumption was $0.468 \mathrm{kWh} \mathrm{kg}^{-1}$ of biodiesel (Motasemi \& Ani, 2012). Later, a similar study was conducted using a microwave reactor for the continuous production of palm oil biodiesel by Choedkiatsakul et al. (2015). The energy consumption for this process include the premixing tank, peristaltic pump, microwave system and cooling system were measured by a plug-in power meter which required $0.1167 \mathrm{kWh}$ $1^{-1}$ of biodiesel. In this study, the energy consumption for the optimal steady state condition is $0.594 \mathrm{kWh}$ for the production of 1 litre of biodiesel using a heterogeneous catalyst.

\section{CONCLUSION}

The application of the continuous flow transesterification of WCO using microwave technology with a perforated plastic container for the solid catalyst on the stirrer could be used to convert WCO to biodiesel. The effects of variables such as power input, stirrer speed and LHSV on the heterogeneous transesterification reaction are very significant. The results obtained clearly show that the RSM-based BBD is a valuable tool that can be used to establish the relationships between the process factors and the responses, with a minimum number of experiments, in a very efficient way. Furthermore, the RSM-based BBD can be used to determine the recommended optimum conditions for the production of biodiesel.

\section{ACKNOWLEDGEMENT}

The authors are grateful to the Ministry of Higher Education (MOHE) Malaysia and Research University Grant, Universiti Teknologi Malaysia, Vot 4L653 for their financial support, and the Research Management Centre, UTM for management support. The first author would like to thank the Governor of South Sulawesi, Indonesia for the scholarship obtained to continue his education at the Universiti Teknologi Malaysia. 


\section{REFERENCES}

Ancheyta, J., 2011. Modeling and Simulation of Catalytic Reactors for Petroleum Refining. New Jersey: John Wiley \& Sons

Aworanti, O.A., Agarry, S.E., Ajani, A.O., 2013. Statistical Optimization of Process Variables for Biodiesel Production from Waste Cooking Oil using Heterogeneous Base Catalyst. British Biotechnology Journal, Volume 3(2), pp. 116-132

Balat, M., Balat, H., 2010. Progress in Biodiesel Processing. Applied Energy, Volume 87(6), pp. $1815-1835$

Borges, M.E., Díaz, L., 2012. Recent Developments on Heterogeneous Catalysts for Biodiesel Production by Oil Esterification and Transesterification Reactions: A Review. Renewable and Sustainable Energy Reviews, Volume 16(5), pp. 2839-2849

Borges, M.E., Díaz, L., 2013. Catalytic Packed-bed Reactor Configuration for Biodiesel Production using Waste Oil as Feedstock. BioEnergy Research, Volume 6(1), pp. 222-228

Buasri, A., Chaiyut, N., Loryuenyong, V., Worawanitchaphong, P., Trongyong, S., 2013. Calcium Oxide Derived from Waste Shells of Mussel, Cockle, and Scallop as the Heterogeneous Catalyst for Biodiesel Production. The Scientific World Journal, Volume 2013, pp. 1-7

Buasri, A., Ksapabutr, B., Panapoy, M., Chaiyut, N., 2012. Biodiesel Production from Waste Cooking Palm Oil using Calcium Oxide Supported on Activated Carbon as Catalyst in a Fixed Bed Reactor. Korean Journal of Chemical Engineering, Volume 29(12), pp. 17081712

Chen, Y.-H., Huang, Y.-H., Lin, R.-H., Shang, N.-C., 2010. A Continuous-flow Biodiesel Production Process using a Rotating Packed Bed. Bioresource Technology, Volume 101(2), pp. 668-673

Choedkiatsakul, I., Ngaosuwan, K., Assabumrungrat, S., Mantegna, S., Cravotto, G., 2015. Biodiesel Production in a Novel Continuous Flow Microwave Reactor. Renewable Energy, Volume 83, pp. 25-29

Dwivedi, G., Sharma, M.P., 2015. Application of Box-behnken Design in Optimization of Biodiesel Yield from Pongamia Oil and Its Stability Analysis. Fuel, Volume 145(0), pp. 256-262

Hamze, H., Akia, M., Yazdani, F., 2015. Optimization of Biodiesel Production from the Waste Cooking Oil using Response Surface Methodology. Process Safety and Environmental Protection, Volume 94(0), pp. 1-10

Han, X.-X., Chen, K.-K., Yan, W., Hung, C.-T., Liu, L.-L., Wu, P.-H., Lin, K.-C., Liu, S.-B., 2016. Amino Acid-functionalized Heteropolyacids as Efficient and Recyclable Catalysts for Esterification of Palmitic Acid to Biodiesel. Fuel, Volume 165, pp. 115-122

Kathirvel, S., Layek, A., Muthuraman, S., 2016. Exploration of Waste Cooking Oil Methyl Esters (WCOME) as Fuel in Compression Ignition Engines: a Critical Review. Engineering Science and Technology, an International Journal, Volume 19(2), pp. 1018-1026

Kusrini, E., Harjanto, S., Yuwono, A.H., 2015. Applications of a Green Chemistry Design, A Clean Environment, and Bioenergy to Promote the Sustainability and Added Value of Products. International Journal of Technology, Volume 6(7), pp. 1065-1068

Lam, S.S., Liew, R.K., Jusoh, A., Chong, C.T., Ani, F.N., Chase, H.A., 2016. Progress in Waste Oil to Sustainable Energy, with Emphasis on Pyrolysis Techniques. Renewable and Sustainable Energy Reviews, Volume 53, pp. 741-753

Levenspiel, O., 1999. Chemical Reaction Engineering. New York: John Wiley \& Sons, Inc.

Li, Z.-H., Lin, P.-H., Wu, J.C.S., Huang, Y.-T., Lin, K.-S., Wu, K C.W., 2013. A Stirring Packedbed Reactor to Enhance the Esterification-transesterification in Biodiesel Production by Lowering Mass-transfer Resistance. Chemical Engineering Journal, Volume 234, pp. 9-15 
Motasemi, F., Ani, F.N., 2012. A Review on Microwave-assisted Production of Biodiesel. Renewable and Sustainable Energy Reviews, Volume 16(7), pp. 4719-4733

Muralidharan, K., Vasudevan, D., 2011. Performance, Emission and Combustion Characteristics of a Variable Compression Ratio Engine using Methyl Esters of Waste Cooking Oil and Diesel Blends. Applied Energy, Volume 88(11), pp. 3959-3968

Nair, P., Singh, B., Upadhyay, S.N., Sharma, Y.C., 2012. Synthesis of Biodiesel from Low FFA Waste Frying Oil using Calcium Oxide Derived from Mereterix mereterix as a Heterogeneous Catalyst. Journal of Cleaner Production, Volume 29-30, pp. 82-90

Pinzi, S., Lopez-Gimenez, F.J., Ruiz, J.J., Dorado, M.P., 2010. Response Surface Modeling to Predict Biodiesel Yield in a Multi-feedstock Biodiesel Production Plant. Bioresource Technology, Volume 101(24), pp. 9587-9593

Rathore, V., Newalkar, B.L., Badoni, R.P., 2016. Processing of Vegetable Oil for Biofuel Production through Conventional and Non-conventional Routes. Energy for Sustainable Development, Volume 31, pp. 24-49

Said, N.H., Ani, F.N., Said, M.F.M., 2015. Review of the Production of Biodiesel from Waste Cooking Oil using Solid Catalysts. Journal of Mechanical Engineering and Sciences, Volume 8, pp. 1302-1311

Talebian-Kiakalaieh, A., Amin, N.A.S., Mazaheri, H., 2013. A Review on Novel Processes of Biodiesel Production from Waste Cooking Oil. Applied Energy, Volume 104, pp. 683-710

Yusuff, A.S., Adeniyi, O.D., Olutoye, M.A., Akpan, U.G., 2018. Development and Characterization of a Composite Anthill-chicken Eggshell Catalyst for Biodiesel Production from Waste Frying Oil. International Journal of Technology, Volume 9(1), pp. 110-119 